\title{
Handbook of Florida Water Regulation: Water Management Districts ${ }^{1}$
}

\author{
Michael T. Olexa, Luke D'Isernia, Laura Minton, Dulcy Miller, and Sarah Corbett ${ }^{2}$
}

\section{Preface}

This handbook is designed to provide an accurate, current, and authoritative summary of the principle Federal and Florida laws that directly or indirectly relate to agriculture. This handbook should provide a basic overview of the many rights and responsibilities that farmers and farmland owners have under both Federal and Florida laws as well as the appropriate contact information to obtain more detailed information. However, the reader should be aware that because the laws, administrative rulings, and court decisions on which this handbook is based are subject to constant revision, portions of this publication could become outdated at anytime. Several details of cited laws are also left out due to space limitations.

This handbook is distributed with the understanding that the authors are not engaged in rendering legal or other professional advice, and the information contained herein should not be regarded as a substitute for professional advice. This handbook is not all inclusive in providing information to achieve compliance with the Federal and Florida laws and regulations governing water protection. For these reasons, the use of these materials by any person constitutes an agreement to hold harmless the authors, the Florida Cooperative Extension Service, the Institute of Food and Agricultural Sciences, and the University of Florida for any liability claims, damages, or expenses that may be incurred by any person as a result of reference to or reliance on the information contained in this handbook.

\section{Overview}

Except for the South Florida and the Southwest Florida Water Management Districts, which were created statutorily to address flooding and water shortage problems, the Florida Water Management Districts (WMD) were created as public agencies pursuant to Chapter 373, Florida Statutes, known as the Florida Water Resources Act of 1972. The WMDs play a significant role in the regulation of agricultural water control and use.

1. This is EDIS document FE594, a publication of the Food and Resource Economics Department, Florida Cooperative Extension Service, Institute of Food and Agricultural Sciences, University of Florida, Gainesville, FL. Published December 2005. Please visit the EDIS website at http://edis.ifas.ufl.edu.

2. Michael T. Olexa, Professor, Food and Resource Economics Department, Florida Cooperative Extension Service, Institute of Food and Agricultural Sciences, University of Florida, Gainesville, FL; Director, Agricultural Law Center, University of Florida, Gainesville, FL; and Chair, Agricultural Law Committee of The Florida Bar. Luke D'Isernia, former student (graduated cum laude in 2005), Levin College of Law, University of Florida, Gainesville, FL. Laura Minton, Attorney, Dean, Mead, Egerton, Bloodworth, Capouano, and Bozarth, Orlando, FL. Dulcy Miller, attorney, Foley and Lardner, LLP, Orlando, FL. Sarah Corbett, Attorney, Florida Second District Court of Appeal, Lakeland, FL.

The Institute of Food and Agricultural Sciences (IFAS) is an Equal Opportunity Institution authorized to provide research, educational information and other services only to individuals and institutions that function with non-discrimination with respect to race, creed, color, religion, age, disability, sex, sexual orientation, marital status, national origin, political opinions or affiliations. U.S. Department of Agriculture, Cooperative Extension Service, University of Florida, IFAS, Florida A. \& M. University Cooperative Extension Program, and Boards of County Commissioners Cooperating. Larry Arrington, Dean 
The WMDs' responsibilities include:

- Management of water and related land resources via promotion of conservation.

- Proper utilization of surface and groundwater resources.

- Regulation of dams, impoundments, reservoirs, and other structures to alter surface water movement.

- Combating damage from floods, soil erosion, and excessive drainage.

- Assisting local governments in developing comprehensive water management plans, particularly by providing data on water resources (WMDs are authorized to perform various field investigations and to provide works for the beneficial storage of water).

- Maintenance of navigable rivers and harbors and the promotion of the health, safety, and general welfare of the people of the state (directly attached to this general welfare consideration is the power to implement water shortage emergency plans).

- Participation in flood control programs and the reclamation, conservation, and protection of lands from water surplus or deficiencies.

- Maintaining water management and use facilities to determine the levels of water to be maintained in each district's bodies of water (districts may establish minimum flows for their works and water courses below which further withdrawals would be significantly harmful to the water resources or ecology, and minimum water levels for surface water and groundwater).

\section{What Is the WMD's Structure?}

Each district is run by a governing board consisting of nine members, except the Southwest Florida Water Management District which has eleven. The members serve four-year terms and are appointed by the Governor and confirmed by the State Senate. The governing board sets the policies that will best effectuate the district's powers. Generally, an executive director is responsible for the operation of the district, including the implementation of policies and rules. Typically, each district is divided into divisions that handle the various permitting programs. Each district is fully equipped to conduct its own inspections, testing, and impact studies.

One district, the Southwest Florida Water Management District, is further divided into watershed basins, which are overseen by basin boards. The board must consist of at least three people, one from each member county. Basin board members are appointed by the Governor, subject to confirmation by the State Senate, and serve staggered three-year terms. Basin boards have the authority to prepare engineering plans for development of water resources, develop secondary water-use plans, submit an annual budget, approve construction plans for works of the district, and plan and provide assistance to local water supply authorities. Basically, Basin Boards are responsible for identifying water resource concerns and problems within their respective areas and adopting budgets to address and fund the resolution of such concerns.

\section{For What Do the WMDs Give Permits?}

WMD governing board powers include administering the permit programs of Chapter 373, Florida Statutes. Thus, WMDs are responsible for permitting the following:

- Wells.

- Management and storage of surface waters.

- Consumptive uses of water.

Each WMD has specific criteria detailing the types of activities that require permits, the contents of permit applications, the procedures that surround submission of an application, and areas specifically exempted from permitting requirements. The Governor and State Cabinet, sitting as the Land and Water Adjudicatory Commission, have authority to review any order or rule of a WMD. 


\section{What Is the State Water Quality Plan?}

The Florida Department of Environmental Protection (DEP) has been directed to prepare the state water use plan and to foster interagency agreements to achieve the State Water Quality Plan. The water use plan is developed by DEP through consultation with federal, state, and local agencies, and particularly the WMDs. The plan includes all water in the state. Its main purpose is to recognize various interests competing for water-use rights and to allocate for these rights while retaining reasonable water quality and quantity control, thus promoting the goals of environmental protection, proper drainage, flood control, and water storage, and ensuring a reliable water supply for Floridians in the future.

In addition, the State Water Quality Plan links the purposes of the Florida Water Resources Act with the purposes of the Florida Air and Water Pollution Control Act, Chapter 403, Florida Statutes, through its water quality standards. The net result is that the DEP retains central responsibility for the collection of scientific data and information regarding water resources, with the central permitting responsibilities being assigned to WMDs.

The DEP also retains direct regulatory power over the following:

- Point source discharges.

- Dredge and fill.

- Groundwater discharges.

- Solid and hazardous waste concerns.

- Leaking underground storage tanks.

In contrast, WMDs are largely responsible for issuing permits for various types of water use, and are the governmental bodies in charge of allocation and control of water resources for which there are many competing interests.

\section{What Can the WMDs Tax?}

Most indicative of their broad powers is the ability of the WMDs to levy ad valorem taxes (property taxes). Ad valorem taxes are levied based on the value of the property in question. The Florida Constitution establishes a millage cap, and millage rates are additionally limited by statute.

Each WMD is different. Taxing authority is vested in the WMDs with basin boards. Basin boards may request that taxes be levied, but may not impose taxes themselves. As with other government tax provisions, a landowne'rs failure to pay can result in a lien on the taxed property, including the homestead, and ultimately, the vesting of title by tax forfeiture to the state.

\section{Acknowledgments}

The authors are indebted to the personnel of both state and federal agencies who provided their time and advice in the preparation of this handbook. The authors are especially indebted to Richard Budell of the Office of Agricultural Water Policy of the Florida Department of Agriculture and Consumer Services for providing funds for the development of this publication. 